\title{
Determinants of Household Expenditure on Primary Education
}

\section{OPEN ACCESS}

Manuscript ID:

ECO-2021-09034021

Volume: 9

Issue: 3

Month: June

Year: 2021

P-ISSN: 2319-961X

E-ISSN: 2582-0192

Received: 04.04.2021

Accepted: 10.05.2021

Published: 01.06.2021

Citation:

Yuvaraj, Nisha, and U. Arabi. "Determinants of Household Expenditure on Primary Education." Shanlax International Journal of Economics, vol. 9, no. 3, 2021, pp. 10-14.

DOI: https://doi.org/10.34293/ economics.v9i3.4021

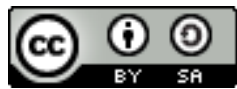

This work is licensed under a Creative Commons Attribution-ShareAlike 4.0 International License

\section{Nisha Yuvaraj}

Research Scholar, Department of Economics

Mangalore University, Mangalore, Karnataka, India

(D) https://orcid.org/0000-0003-3464-0113

\section{U. Arabi}

Professor, Department of Economics, Mangalore University, Mangalore, Karnataka, India

\section{Abstract}

Government expenditures and household expenditures appear to act as complements rather than substitutes for each other: an increase in government expenditure tends to increase household expenditures and vice-versa. Public investment can provide educational facilities, quality, and other institutional measures, but only household investment will enable its utilization.

Keywords: Household, Primary education, School-related variables, Public investment, Expenditure, Substitutes

\section{Introduction}

The main characteristics of the home, which can be called social, cultural, educational, professional and other factors, can influence the nature and amount of investments made in the education of home children and determine where policy actions should be prioritized. Important determinants of household educational expenditure include household income, academic level of the head of the household, the size of the family, caste and religion, school-related variables such as the provision of mid-day meals, uniforms, textbooks and stationery, and the availability of school within the habitation are also quite important. Unfortunately, not much research has been done on the extent of household spending on education or the determinants of home spending decisions. The purpose of the present study is to examine the various parameters under which household members make decisions about investing in elementary education in Karnataka. In particular, it looks at how the amount spent on education by householders responds to changes in household income and government education spending.

\section{Literature Review}

Chernichovsky (1985), in his study on school enrolment in rural Botswana, finds that the number of children aged 7-14 in the household has a positive effect on the demand for schooling. This runs contrary to the quantity-quality trade-off.

This observed effect on perceived opportunity costs to education is a combination of age and family size factors.

Tilak (1988), The indirect cost is the foregone earning or the opportunity cost of the child attending school. It is also known as the invisible cost, which is generally not included in estimating household expenditure on education but is substantial. 
Banerjee, Rukmini (2000), The inadequacy of the school system to attract and keep children is more crucial than households' economic conditions. School enrolment has risen dramatically in cities and villages, but the ability of the government school system to retain and adequately educate children has been less impressive. The study suggested adopting a flexible approach, accountability to the community, innovative actions at the local level, whether in the classroom or the community, must be recognized for the universalization of primary education in India.

\section{Objectives}

- To examine the extent, the pattern, and the determinants of household expenditure on primary education in the study area.

- To analyze the redistributive impact in public spending on primary education in Karnataka.

\section{Research Methodology}

The study adopted different parameters to evaluate the benefits of public spending, including household expenditure in the total spending on primary education. The study used various methods for the analysis of government involvement in primary education through public expenditure. The proposed research describes and analyzes based on secondary data.

\section{Data Analysis and Interpretations}

A number of schools are indicative of the size of a system. Karnataka reported 56441 primary schools in 2007-08, which has increased by 4818 schools which became 61259 in 2016-17. There are 76551 schools in the State in 2016-17 of which 26100 are lower primary, 35159 are higher primary and 15292 are high schools. The ratio between lower and higher primary schools is 1:1.34; like-wise, the balance between higher primary and high schools is 2.30:1. Article 21 A of the Constitution of India and the Right of children to free and compulsory education (RTE) Act 2009 became operative in April 2010. The state rules under RTE Act were notified in 2011. These developments have thrown open fresh opportunities for quality schooling for children.

Household spending on education may be influenced by household characteristics, which cannot be considered in the state-level analysis. It is therefore hoped that the study based on household data will provide an in-depth understanding of the determinants of household spending on education. The choice of variables is influenced by the availability of data. It is also clear that the social, economic, and demographic characteristics of households have a significant influence on the level of household spending on education. It is argued that the expected rate of return will significantly affect domestic investments in education - the rate of return on education, current levels of family investments will be higher, and vice versa.

- The size of the house can be considered as an indicator of the 'demographic burden' on the household. Larger households with male and female children and other household members can result in lower levels of education costs.

- Secondly, in individual characteristics, the gender of the child going to school is considered the most essential factor. The general prevalence of gender discrimination suggests that, compared to men, households spend less on educating their girl children.

- The third set of factors relates to schools. It is expected that family expenses will complement or change people's efforts. A significant correlation can be expected between household costs on the one hand and the quality and quantity of education facilities available on the other. More specifically, the provision of school incentives, such as mid-day meals, textbooks, etc., would be negatively related to household expenses. Variables on these three indicators, such as the supply of mid-day meals, books and stationery, and the provision of uniforms, are used here.

- Finally, the fourth factor is the level of development of the village. Individual and household decisions are significantly influenced by the social environment. While the whole social environment cannot be extensively captured by a single indicator, the level of development of the village can be expected to be reflected in the social environment in which the houses are located. 


\section{Costs Incurred by Households on Education}

Household costs on education consist of direct and indirect costs of education. Direct household costs include tuition fees, examination fees, admission fees and various other forms of prices and payments to the school. Yet other parts of direct costs are the expenditure incurred not necessarily on schools but on other essential items such as books, stationery, uniforms, transport and such additional spending, which may be referred to as the maintenance cost.

As far as gender variations are concerned, in the rural areas, at the primary level, there is no difference in expenditure levels between males and females. Even at the upper primary level, a litter higher level of expenditure is incurred on female students. But in urban Karnataka, the girls are not in an advantageous position. The gap persists and perhaps widens at the upper primary level of education between regions.

The following table shows the various household expenditure on education in the state of Karnataka based on the income level of the households in the state.

Table 1: Household Expenditure on Education as a Percentage of Household Income by Income Group

\begin{tabular}{|c|c|}
\hline Household income (Rs.) & \% of household expense \\
\hline Upto 10000 & 8.39 \\
\hline $10001-20000$ & 2.98 \\
\hline $20001-30000$ & 2.42 \\
\hline $30001-40000$ & 2.28 \\
\hline $40001-50000$ & 1.01 \\
\hline $50001-60000$ & 1.27 \\
\hline $60001-70000$ & 0.78 \\
\hline $70001-80000$ & 1.03 \\
\hline $80001-90000$ & 0.46 \\
\hline Above 90000 & 0.37 \\
\hline Total & $\mathbf{3 . 5 2}$ \\
\hline
\end{tabular}

The above table shows that the families with low income spend more share of their income on education. In contrast, families spend a common share of their income on education as the income of the households increases. The percentage was $8.39 \%$ of the household expense for the families with less than Rs.10000. The percentage has decreased drastically to $0.37 \%$ for the families with more than Rs.90000 income among the households.

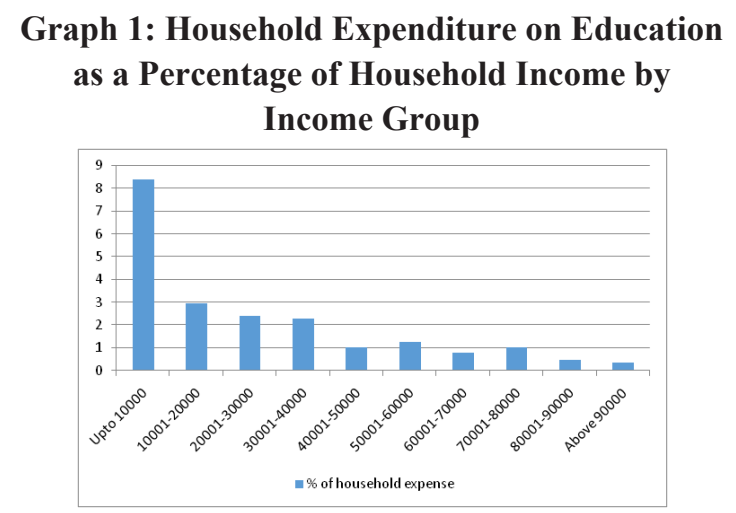

Households are likely to respond to policy interventions that affect school inputs. In the education production function framework, a key question is whether an increase in school inputs leads to an increase in inputs provided by parents (the two sources of inputs would complement) or to a decrease (the two sources would be substitutes).

One can expect a positive relationship between the village development index and the household expenditures on education. The significant variables considered are listed below:

\section{School-Related Factors}

- Existence of school within the habitation

- Existence of incentive schemes in schools such as the provision of mid-day meals, supply of free uniforms, free textbooks and stationery, etc. in schools

- Pupil-teacher ratio

- Trained teachers (\% of all teachers) in school

- Type of institution (government, governmentaided, or private) the child attends

\section{Infrastructure Facilities}

The Sarva Shiksha Abhiyan accorded special significance and weightage for the provision of infrastructure facilities to schools. Eight facilities are recognized as Basic Facilities for schools comprising Common Toilets, Girls' Toilets, Electricity, Play Ground, Ramps, Library, Compound, and Drinking water. 


\section{Table 2: Fundamental facilities in Primary schools}

\begin{tabular}{|c|c|c|c|c|c|c|c|c|}
\hline Year & $\begin{array}{c}\text { Toilet for } \\
\text { Boys }\end{array}$ & $\begin{array}{c}\text { Toilet for } \\
\text { Girls }\end{array}$ & Electricity & $\begin{array}{c}\text { Play } \\
\text { ground }\end{array}$ & Ramps & $\begin{array}{c}\text { Wall } \\
\text { compound }\end{array}$ & $\begin{array}{c}\text { Drinking } \\
\text { water }\end{array}$ & Library \\
\hline $2007-08$ & 78.76 & 46.25 & 80.49 & 42.14 & 45.46 & 63.13 & 70.65 & 76.28 \\
\hline $2008-09$ & 82.95 & 50.23 & 84.44 & 49.00 & 52.10 & 68.20 & 80.54 & 86.44 \\
\hline $2009-10$ & 88.66 & 64.66 & 87.56 & 52.06 & 64.62 & 59.59 & 88.13 & 86.98 \\
\hline $2010-11$ & 91.97 & 74.26 & 91.89 & 54.41 & 72.95 & 66.61 & 93.59 & 91.86 \\
\hline $2011-12$ & 97.91 & 98.81 & 95.49 & 54.34 & 78.27 & 69.21 & 99.55 & 98.66 \\
\hline $2012-13$ & 99.72 & 99.90 & 99.56 & 55.74 & 79.83 & 73.48 & 99.92 & 99.35 \\
\hline $2013-14$ & 99.97 & 99.98 & 98.71 & 56.30 & 80.96 & 75.48 & 99.99 & 99.66 \\
\hline $2014-15$ & 99.76 & 99.94 & 98.99 & 56.87 & 83.37 & 77.33 & 99.98 & 99.73 \\
\hline $2015-16$ & 99.28 & 99.72 & 98.71 & 57.02 & 83.34 & 78.37 & 99.94 & 99.74 \\
\hline $2016-17$ & 97.13 & 98.63 & 97.67 & 57.31 & 61.80 & 78.77 & 99.78 & 99.67 \\
\hline
\end{tabular}

Source: DISE report of Karnataka 2007-08 to 2016-17

\section{Graph 2: Fundamental Facilities in Primary} Schools

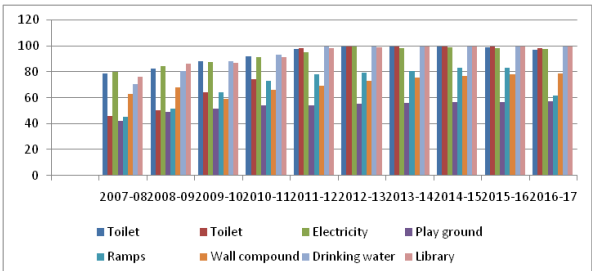

Source: DISE report of Karnataka 2007-08 to 2016-17

\section{Findings}

- $97.9 \%$ of schools have a library.

- $17.2 \%$ Schools provide MDM but not prepare in School Premises.

- $99.2 \%$ of Government Schools received textbooks.

- $94.9 \%$ Schools providing Mid-day meal have kitchen-shed.

- $44.8 \%$ of Schools have handwash facilities near toilets.

- $33.8 \%$ Schools have Electricity and Computer.

\section{Conclusion}

As far as household item wise spending on education is concerned, fees and transportation make it the most important thing at any level of education. It is imperative to make it fee-free and provide transport facilities at all levels of education. It is well known that there is a severe shortage of resources in the field of education in India. So the government will have to increase its allocation in the education sector significantly. The results also suggest that the gap between male and female household spending at all levels of education indicates that boys spend less on their girls' education than their children. Therefore, it should be allocated separately to girl students at all levels of education, as the child going to school is considered the most essential factor.

\section{References}

Aggarwal, Yash. Access and Retention under DPEP: A National Overview. National Institute of Educational Planning and Administration [NIEPA], 1998.

A handbook of Karnataka. Government of Karnataka, 2005.

Annual Reports (2006-2018). Department of Primary and Secondary Education, Karnataka.

Attending an Educational Institution in India: Its Level, Nature and Cost: NSS 52nd Round (1995-1996). National Sample Survey Organisation, Ministry of Statistics and Programme Implementation, Government of India, 1998.

Banerji, Rukmini. "Poverty and Primary Schooling: Field Studies from Mumbai and Delhi." Economic and Politicla Weekly, vol. 35, no. 10, 2000, pp. 795-802.

Bhatty, Kiran. "Educational Deprivation in India A Survey of Field Investigations." Economic and Political Weekly, vol. 33, no. 27, 1998. 
Chernichovsky, Dov. "Socioeconomic and Education in India, School Education (Numerical Demographic Aspects of School Enrollment and Attendance in Rural Botswana." Economic Development and Cultural Change, vol. 33, no. 2, 1985, pp. 319-332.

Child Census and Household Survey. Government of Karnataka, 2004.

Duraisamy, Malathy. "Demand for and Access to Schooling in Tamil Nadu." Elementary Education in Rural India: A Grassroots View. Edited by Vaidyanathan, A., and P.R. Gopinathan Nair, Sage Publications, 2001.

Early Childhood Care and Education - An Overview. Ministry of Human Resource Development, Government of India, 2003. Data) 1998-99. Ministry of Human Resource Development, Government of India, 2005.

Govinda, R., and K. Biswal. Elementary Education in India: Promise, Performance and Prospects. UNDP, 2006.

Khera, Reetika. "Mid-Day Meals in Primary Schools: Achievements and Challenges." Economic and Political Weekly, vol. 41, no. 46, 2006.

Medium Term Fiscal Plan 2003-04 to 2006-07. Government of Karnataka.

SSA Annual Report 2006-07 (Karnataka). SSA Mission, Karnataka, Bangalore, 2006.

Vaidyanathan, A., and P.R. Gopinathan Nair. Elementary Education in Rural India: A Grassroots View. Sage Publications, 2001.

\footnotetext{
Author Details

Nisha Yuvaraj, Research Scholar, Department of Economics, Mangalore University, Mangalore, Karnataka, India, Email ID: yn025051@gmail.com
}

U. Arabi, Professor, Department of Economics, Mangalore University, Mangalore, Karnataka, India 